\title{
HUKUM ISLAM DAN BUDAYA LOKAL TELAAH UNSUR LOKALITAS DALAM PEMBENTUKAN HUKUM ISLAM
}

\author{
Mohammad Ikhwanuddin ${ }^{1}$ \\ e-mail : ikkhwa.nuddin@gmail.com \\ STAI TARUNA SURABAYA
}

\begin{abstract}
Abstrak : Diskursus mengenai Hukum Islam dan budaya lokal sering kali tidak berjalan dengan baik. Keberadaan budaya yang dianggap merupakan hasil cipta manusia dan berjalan dinamis progresif, dipandang memiliki karakter yang berlainan dengan hukum Islam di mana tekstualitas dalil pembentukan hukum Islam bersumber pada dua hal yang paling penting dalam setiap pembentukan hukum, yakni Al-Qur'an dan Hadis. Akan tetapi, dalam tataran teori dan praktis, pembentukan hukum Islam ternyata tidak sama sekali menegasikan nuansa lokalitas. Persinggungan keduanya memiliki relasi yang saling terikat dalam pembentukan awal hukum Islam. Islam, dengan sumber hukumnya, berakulturasi dengan indah dengan unsur lokalitas ternyata mampu menyadarkan kembali pertentangan yang kembali, dan akan terjadi berulang, mengenai hukum Islam dan budaya lokal.
\end{abstract}

Kata Kunci: Hukum Islam, Budaya, dan Pembentukan Hukum.

\section{A. PENDAhuluan}

"Hukum adat bersendi syara', syara' bersendi Kitabullah". ${ }^{2}$ Keberadaan nuansa lokal dalam pembentukan hukum Islam sering kali dianggap sebagai suatu yang absurd dan tidak mendasar. Idris Ramulyo dalam Asas-Asas Hukum Islam; Sejarah Timbul dan Berkembangnya Kedudukan Hukum Islam dalam Sistem Hukum di Indonesia, menukilkan kalimat di atas, "Hukum Adat bersendi Syara', Syara' bersendi Kitabullah", sebagai konklusi akomodatif hasil pertentangan berkepanjangan antaras masyarakat adat (lokal) dengan kaum agama (Islam).

Pergumulan dalam nuansa kontradiktif tersebut memendarkan sebuah anggapan bahwa pada awal pembentukan hukum Islam, Islam hadir dengan tanpa memberikan ruang dialogis yang relevan dengan unsur lokal. Hal inilah yang memunculkan ketegangan antara keduanya, di mana hukum Islam yang hadir di banyak tempat sering kali mengalami pergesekan dengan unsur loyalitasnya.

Pergumulan ini pada akhirnya meniscayakan adanya pola interaksi yang baik. Kendati pembauran tersebut dimuali dari sebuah entitas yang berbeda, namun interaksi hukum Islam dan budaya lokal, untuk tidak mengatakan selalu, mampu menghasilkan sebuah paduan yang menarik. Paduan instrumen tersebut kemudian membaur, berpadu dalam sebuah tatanan tertentu yang -bahkan- menghasilkan warna baru, atau malah bersifat saling mempengaruhi. Tindakan saling mempengaruhi ini, kendati dalam

\footnotetext{
${ }^{1}$ Dosen STAI Taruna Prodi Ahwal Syakhsiyah

2 Mohd. Idris Ramulyo, Asas-Asas Hukum Islam; Sejarah Timbul dan Berkembangnya Kedudukan Hukum Islam dalam Sistem Hukum di Indonesia, (Jakarta: Sinar Grafika, 1995), 46-47.
} 
pandangan A Qodry Azizi ${ }^{3}$ tidak terlalu penting untuk menentukan siapa mempengaruhi siapa, menjadi tidak mengherankan jikalau dalam peribahasa dikenal dengan kalimat "Adat bersendi Syara', Syara' bersendi adat".

Kendati demikian, pelacakan persinggungan hukum Islam dan budaya lokal dalam tataran praktis-formil tidak bisa dikesampingkan, terlebih pada sisi pembentukan hukum Islam itu sendiri. Oleh karena itu, menegasikan salah satunya hanya dapat menghasilkan pembacaan mengenai hukum menjadi tidak akurat, dan kurang komprehensif.

\section{B. Hukum Islam Dan Budaya, Dari Pengertian Menuju Problematik}

Dalam menyibak persinggungan Hukum Islam dan Budaya Lokal, kebutuhan informasi, meskipun sepintas dan ringkas, mengenai definisi keduanya masih dibutuhkan. Walaupun sudah dibahas dan sudah teramat jelas, namun pada tataran definitif, istilah keduanya menjadi mutlak untuk diuraikan terlebih dahulu sebelum memaparkan persinggungan keduanya.

Hukum Islam, dalam pengertian yang sederhana pernah diutarakan oleh Hasby Ash-Shiddiqie sebagai koleksi daya upaya para ahli hukum untuk menerapkan syariat atas kebutuhan masyarakat. ${ }^{5}$ Pengertian Hukum Islam tersebut, menurut Amir Syarifuddin lebih cenderung pada redaksional "fikih" dari pada merujuk pada pengertian syariat, sehingga Amir Syarifuddin lebih memilih mengartikan Hukum Islam sebagai seperangkat peraturan berdasarkan wahyu Allah dan Sunnah Rasul tentang tingkah laku manusia muallaf yang diakui dan diyakini berlaku dan mengikat untuk semua umat yang beragama Islam. ${ }^{6}$ Sementara budaya, dan atau kebudayaan merupakan pikiran, akal budi, hasil dari penciptaan atau akal budi manusia. ${ }^{7}$ Atau dapat juga diartikan sebagai keseluruhan cara hidup manusia. ${ }^{8}$

Pada ruang definisi tersebut sebenarnya sudah memunculkan sedikit masalah problematik, yakni pada tataran di mana Hukum Islam berdasarkan pada wahyu dan Sunnah Rasul, sementara budaya adalah hasil ciptaan manusia. Sisi problematik tersebut pernah disinggung oleh tokoh yang membumikan gagasan "Pribumisasi Islam" Abdurrahman Wahid sebagai berikut: " Agama Islam bersumberkan wahyu dan memiliki norma-normanya sendiri. Karena bersifat normatif, maka ia cenderung

\footnotetext{
3 A. Qadri Azizy. Eklektisisme Hukum Nasional:Kompetensi antara Hukum Islam dan Hukum Umum, (Yogyakarta: Gama Media, 2002), 87-103.

${ }^{4}$ Pusat Bahasa yang mengoleksi sebuah paribahasa "Adat bersendi Syara', Syara' bersendi adat" ini mengartikannya sebagai "perbuatan hendaknya selalu mengingat aturan adat dan agama". Dengan melihat definisi ini, di titik pemahaman tertentu, adat dan agama bisa dipandang sebagai entitas yang berbeda namun tetap dijadikan sebuah pijakan/pertimbangan dalam bertindak. Tim Penyusun Kamus Pusat Bahasa, Kamus Bahasa Indonesia, (Jakarta: Pusat Bahasa, 2008), 10.

${ }^{5}$ Hasby Ash-Shiddiqie, Filsafat Hukum Islam ( Jakarta: Bulan Bintang, 1975), 44. Lihat pula Amir Syarifuddin, "Pengertian dan Sumber Hukum Islam" dalam Ismail Muhammad Syah (et.al), Filsafat Hukum Islam, cet.III (Jakarta: PT Bumi Aksara, 1999), 17.

6 Amir Syarifuddin, "Pengertian dan Sumber Hukum Islam" dalam Ismail Muhammad Syah (et.al), Filsafat Hukum Islam, 18.

${ }^{7}$ Tim Penyusun Kamus Pusat Bahasa, Kamus Bahasa Indonesia, 225.

${ }^{8}$ Clyde Cluckhon, "cermin bagi manusia" dalam Parsudi Suparlan (ed), Manusia, Kebudayaan dan Lingkungannya, (Jakarta: Rajawali, 1984), 69
} 
menjadi permanen. Sedangkan budaya adalah buatan manusia, karenanya ia berkembang sesuai perkembangan zaman dan cenderung untuk selalu berubah". 9

Nuansa problematik di atas hendaknya dipahami sebagai bagian dari persinggungan dua instrumen yang berlainan karakter yang sedang mewujud menjadi sebuah wajah baru. Upaya mempertautkan atau melakukan rekonsiliasi antara hukum Islam dan budaya lokal, menurut Abdurrhman Wahid, sebenarnya bukan karena kekhawatiran terjadinya ketegangan antara keduanya, namun hal ini bertitik tolak pada pemahaman bahwa wahyu harus dipahami dengan mempertimbangkan faktor-faktor kontekstual, termasuk kesadaran hukum dan rasa keadilannya. ${ }^{10}$

Di sini letak urgensitas pertautan antara Hukum Islam dan Budaya Lokal. Bahwa keberadaannya bukan hendak menegasikan satu sama lain, namun dapat berwujud sebagai rekonsiliasi harmonis di mana Islam hadir dengan seperangkat aturan yang akan diterapkan dalam suatu kondisi masyarakat yang memiliki sebuah latar belakang istiadat yang berbeda.

Pemahaman ini secara gradual dapat menghantarkan kita pada sebuah simpul sederhana mengenai urgensitas wahyu al-Quran, misalnya, yang dipahami secara komprehensif dengan mempertimbangkan adat istiadat di mana wahyu tersebut diturunkan ${ }^{11}$. Pada saat bersamaan, menyitir ungkapan Peter L. Berger, "That our position has not sprung up ex nihilo... (posisi kami tidaklah muncul dari keadaan kosong...)"12, keberadaan sesuatu tidaklah muncul dari ruang hampa. Pembentukan Hukum Islam, pada gilirannya, selalu akan bersinggungan dengan unsur lokalitas di mana Islam hadir, baik dengan cara akomodatif maupun malah menegasikannya.

Tentu saja, berjejal hal yang masih perlu dipahami sebelum menyingkap segenap hal yang saling bersinggungan, bahkan berseteru, dalam wujud rekonsiliasi yang saling berinteraksi. Interaksi ini pula yang mendasari Dede Rosyada menjelaskan terwujudnya pranata sosial dalam masyarakat muslim di mana ia mengartikan pranata sosial sebagai tradisi-tradisi dalam kehidupan manusia yang terbentuk sebagai kombinasi antara reaksi kemanusiaan atas tantangan dan dinamika lingkungannya, dengan etos yang menjadi nilai dasar kehidupannya. Bagi umat Islam, nilai etos itu terbentuk dari ajaran-ajaran dasar yang dikembangkan al-Quran dan Al-Sunnah. ${ }^{13}$

Kendati merupakan entitas yang berlainan, hukum Islam dan budaya masih dianggap memiliki jalan (terjal) yang panjang dalam perwujudan pranata sosial (tradisi) masyarakat muslim. Pada saat tertentu, interaksi ini kemudian mengerucut menjadi wajah "baru" dalam pembentukan hukum Islam, meskipun sering kali menghadirkan wajah yang kaku, dalam nuansa yang kontradiktif.

\footnotetext{
${ }^{9}$ Abdurrahman, "Pribumisasi Islam" dalam Muntaha Azhari dan Abdul Mun'im Saleh (Ed.), Islam Indonesia Menatap Masa Depan, (Jakarta: P3M, 1989), 81.

${ }^{10}$ Abdurrahman, "Pribumisasi Islam", 82.

11 Al-Sha>t\}iby, seorang mujtahid dalam memahami al-Qur'an harus memahami dengan betul $a s b a>b$ al-tanzi $>l$ (istilah lain $a s b a>b$ al-nuzu>l/ sebab-sebab turunnya al-Qur'an) dan adat (tradisi) masyarakat Arab pada saat ayat al-Qur'an diturunkan. Lihat Abu $>$ Ish $/ a>$ q Ibra $>$ hi $>\mathrm{m}$ bin $\mathrm{Mu}>\mathrm{sa}$ al-Lakhmi $>$ al-Ghirna $>\mathrm{t}$ j $\mathrm{i}>\mathrm{al}-\mathrm{Ma}>\mathrm{liki}>\mathrm{Al}-\mathrm{Sha}>\mathrm{t} / \mathrm{ibi}>$, al-Muwa $>$ faqa $>t$ fi $>U s\} u>l$ al-Shar>i'ah, j.III (Beirut: Da>r al-Ma'rifah,1975), 277-281

${ }^{12}$ Peter L. Berger, "Prefece" dalam Peter L. Berger dan Thomas Luckmann, The Social Construction Of Reality: A Treatise in The Sociology Of Knowlodge (London: Penguin Group, 1991), 8.

13 Dede Rosyada, Hukum Islam dan Pranata Sosial; Dirasah Islamiyah III (Jakarta: Rajawali Press, 1993), 163
} 
Untuk mengurai kembali wujud relasi nuansa lokalitas dalam pembentukan hukum Islam, beberapa kajian mengenai pelandasan budaya lokal dalam pembentukan hukum Islam menjadi mutlak dibutuhkan.

\section{Landasan Budaya Dalam Pembentukan Hukum Islam}

Pada pengertian budaya di atas, kendati banyak pengertian yang berlainan, namun pada dasarnya pengertian budaya selalu akan berorientasi pada manusia selaku pencipta. Budaya yang hidup di masyarakat, yang mengandung segala aturan perbuatan yang menjadi kebiasaan secara turun-temurun dinamakan adat istiadat. ${ }^{14}$ Dalam bahasa arab, adat istiadat diterjemahkan sebagai $a l$ - ' $a>$ dat atau $a l$ - 'urf.

Kendati dalam beberapa literatur ada yang memilah mengenai pengertian al' $a>$ dat atau al-'urf dalam sebuah definisi yang berbeda, namun dalam domain istilah para pakar Hukum Islam (lisa>n al-shar'iyyi $>$ n), menukil ungkapan Abd. Wahha>b Khallaf, tidak ada perbedaan. Artinya ungkapan mengenai $a l$-' $a>d a t$ atau $a l$-'urf memiliki arti yang sama yakni:

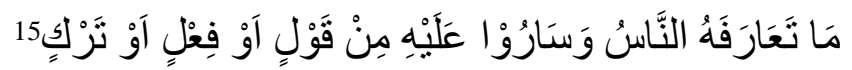

"Sesuatu yang telah dikenal oleh manusia dan mereka mengikutinya, baik berupa ucapan, perbuatan atau meninggalkan sesuatu".

Pengertian adat tersebut menjelaskan mengenai adat yang berupa perkataan dan berbuat/tidak berbuat, merupakan sebuah jalan hidup yang telah dilakukan oleh masyarakat dan telah dikenal sebagai bagian dari cara bermasyarakat.

Untuk melengkapi definisi di atas, pengertian adat dapat ditemukan seperti didefinisikan sebagai berikut:

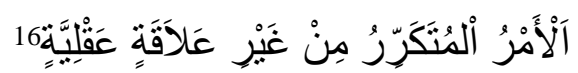

"Sesuatu yang dikerjakan secara berulang-ulang tanpa adanya relasi rasional".

Definisi yang kedua hendak mendedahkan pengertian adat dalam sisi keberulangannya dengan tanpa muatan unsur rasional. Artinya, adat telah dikerjakan oleh manusia secara turun-temurun, berkelanjutan, dan berulang kali dengan mengesampingkan pertimbangan-pertimbangan rasional.

Sebagai dasar yang paling utama dalam pembentukan hukum Islam, Al-Quran merekam landasan tekstual mengenai al-'adat atau al-'urf yang, di antaranya, terdapat dalam Surat al-A'raf: 199:

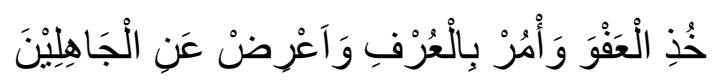

"Berikanlah Maaf (wahai Muhammad) dan perintahkanlah sesuatu yang baik dan berpalinglah dari orang-orang yang bodoh".

Kata al-'urf pada ayat di atas dapat diartikan sebagai kebiasaan (adat) yang dilakukan oleh manusia. ${ }^{17}$ Pada pengertian yang sama pula, Wahbah al-Zuh\}aily memberikan komentar dalam tafsirnya mengenai kata "khudh bi al- 'urf" sebagai berikut:

\footnotetext{
${ }^{14}$ Tim Penyusun Kamus Pusat Bahasa, Kamus Bahasa Indonesia, 10

15 Abdul Wahhab Khalaf, Ilm Us\} $u>l$ Fiqh, (Indonesia: al-H \}aramayn, 2004), 89

${ }^{16} \mathrm{Ah}$ /mad Fahmi Abu> Sunnah, al- 'Urf wa al-A>dah fi>Ra'y al-Fuqaha>' (Mesir: Da>r al-Fikr, al-`Arabi>, t.th.), 8 .

17 Syahrowardi dan M. Imdad Robbani (eds), Formulasi Nalar Fiqh; Telaah Kaedah Fiqh Konseptual (Surabaya: Khalista, 2006), 269.
} 


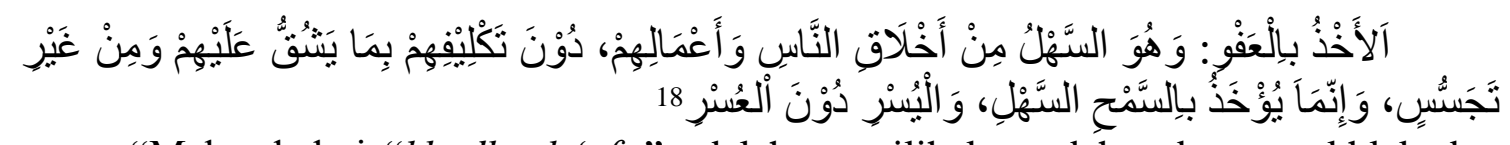

"Maksud dari "khudh al- "afw" adalah memilih kemudahan berupa akhlak dan segenap prilaku masyarakat serta tidak membebani mereka dengan sesuatu yang memberatkan serta tanpa memata-matai. Pemilihan kemudahan tersebut dengan mengedepankan toleransi dan kemudahan bukan dengan kesukaran."

Oleh karenanya dapat dipahami, bahwa penerapan hukum Islam selalu didorong dan didasari untuk selalu mempertimbangkan prilaku masyarakat yang telah dikenal/dijalani, dengan mempertimbangkan toleransi dan kemudahan. "Prilaku masyarakat" yang terdapat dalam ulasan tersebut hendak menegaskan adanya interaksi yang -diharapkan- bagus dalam berdakwah, termasuk dalam pembentukan dan pemberlakuan hukum Islam.

Kendati ayat tersebut dapat diartikan seperti itu, namun untuk menjadikannya landasan dalam 'urf sebagai pembentuk hukum tidak disepakati bersama. Abd. al-Karim Zaydan berpendapat bahwa ayat tersebut semestinya dipahami sebagai etika dakwah Rasulullah dalam menghadapi orang Arab yang berkarakter keras, dengan dakwah yang dilakukan dengan cara yang baik dan lemah lembut. ${ }^{19}$ Argumentasi ini bisa pula diterima bahwa maksud ayat tersebut adalah perintah kepada Nabi agar berprilaku yang baik dalam penyampaian risalah. Namun, adopsi landasan lokalitas dalam pembentukan hukum bisa jadi menjadi hal yang kontradiktif.

Sisi kontradiktif ini pula yang mengarahkan seorang ulama yang telah mengklaim diri sebagai mujtahid Imam al-Suyuti ${ }^{20}$ memperkuat landasan 'urf yang dapat membentuk Hukum Islam, dengan hadis yang berbunyi:

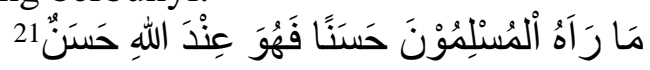

"Segala sesuatu yang dipandang kaum muslimin sebagai sesuatu yang baik, maka hal itu baik pula menurut Allah".

Kendati hadis tersebut telah terkenal di kalangan para peneliti hadis, namun setelah melalui penelusuran yang jeli Muhammad Sidqy bin Ahmad al-Burnu, seperti menukil pendapat al-'Allaiy, menyimpulkan bahwa hadis tersebut tidak ditemukan dalam kualitas marfu' (sanad bersambung tanpa terputus sampai ke Rasulullah), namun hadis tersebut disandarkan pada perkataan Abdullah bin Mas'ud secara mauquf (matan hadis terhenti sampai di sahabat). ${ }^{22}$

Pada proses kristalisasi gagasan menjadikan adat sebagai hukum, atau dikenal dalam kaum juris Islam sebagai al-'adat al-muhłakkamah, Muhammad Sidqi bin Ah \}mad al-Burnu mengartikan hal itu dalam tataran domain fikih menjadi:

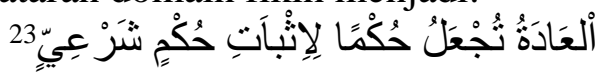

\footnotetext{
18 Wahbah bin al-Mustafa al-Zuhayly, al-Tafsir al-Munir fi al-'Aqidah wa al-Shariah wa alMinhaj, Juz.ix (Damaskus: Dar al-Fikr, 1418 H), 217.

${ }^{19}$ Syahrowardi dan M. Imdad Robbani (eds), Formulasi Nalar Fiqh, 270. Lihat pula Abdul Karim Zaydan, al-Wajiz fi Usul al-Figh (t.t: Muassasat al-Risalah, 2001), 254.

${ }^{20}$ Jalal al-Din Abd. al-rahman bin Abi Bakr al-Suyuti, al-Ashbah wa al-Nazair fi al-Furu', (Surabaya: al-Hidayah, 1965), 63

${ }^{21}$ Abu Abdillah Ahmad bin Hanbal al-Shaybani, Musnad Ahmad bin Hanbal, Juz.I (al-Qahirah: Muassasat Qurtuba, t.th), 379

${ }^{22}$ Muhammad Sidqy bin Ahmad al-Burnu, al-Wajiz fi Idah Qawa'id al-Fiqh al-Kulliyat (al-Riyad: Muassasat al-Risalah, t.th), 152-153.

${ }^{23}$ Muhammad Sidqi bin Ahmad al-Burnu, al-Wajiz, 156.
} 

syariat".

"Bahwa adat istiadat dijadikan sebagai hukum tak lain untuk menetapkan hukum

Pengertian di atas, mulai menampakkan sisi terang ruang problematik antara hukum Islam dan Budaya Lokal, di mana adat istiadat masih dipertimbangkan dalam pembentukan atau penetapan sebuah hukum syariat.

Secara lebih spesifik, adat istiadat yang dapat bersinggungan dengan hukum Islam dapat dilihat dari klasifikasi yang diberikan oleh Imam al-Shatibi dalam 2 kategori mengenai budaya lokal (al-'adat $)^{24}$ :

Pertama:

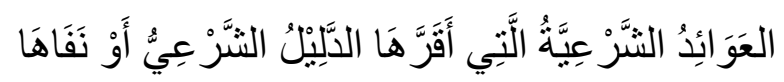

“Adat shar'i yang telah diakui oleh syariat (ditetapkan keabsahannya oleh syariat) atau telah dinafikan/dilarang oleh syariat".

Maksud imam Shatibi di sini adalah memposisikan adat yang telah mendapatkan respons dari dalil syariat, baik dengan melegalkannya secara akomodatif maupun dengan menegasikannya dengan prinsip peniadaan melalui larangan.

Kedua:

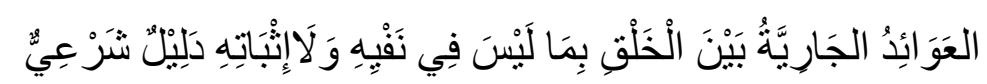

"Adat yang berlaku di tengah-tengah masyarakat yang belum ditemukan dalil syari yang meniadakannya (melarangnya) maupun menetapkan (melegalkannya)".

Dalam katagori yang kedua ini, imam Shatibi hendak memberikan sebuah perluasan kategori di mana pada prinsipnya, adat banyak yang berlaku di masyarakat dengan tanpa/belum mendapatkan respons dari dalil syar'i baik dengan menetapkannya (ithbat) atau melarangnya (nafy).

\section{Akulturasi Hukum Islam dan Unsur Lokalitas, Beberapa Contoh}

Pada ruang praktis, hukum yang berada dalam masyarakat memiliki keragaman yang tidak tunggal. Maka untuk alasan ini pula, saat membicarakan mengenai sumber hukum Indonesia, misalnya, Qadry Azizy mengakui adanya hukum agama, hukum adat dan hukum Barat. ${ }^{25}$ Artinya, dalam masyarakat, adanya hukum yang tidak tunggal tersebut memungkinkan, untuk tidak mengatakan selalu dan pasti, terjadi sebuah gesekan dan proses rekonsiliasi yang panjang dalam menemukan bentuk yang ideal. Hal ini pula yang terjadi dalam kaitan Hukum Islam dan Budaya Lokal.

Untuk lebih meneropong akulturasi Hukum Islam dan budaya lokal, penulis akan memberikan beberapa contoh yang mengindikasikan adanya akulturasi yang sinergis dan harmonis antara keduanya di masa pembentukan hukum Islam dalam dua contoh:

1. Kasus Perusakan Kebun

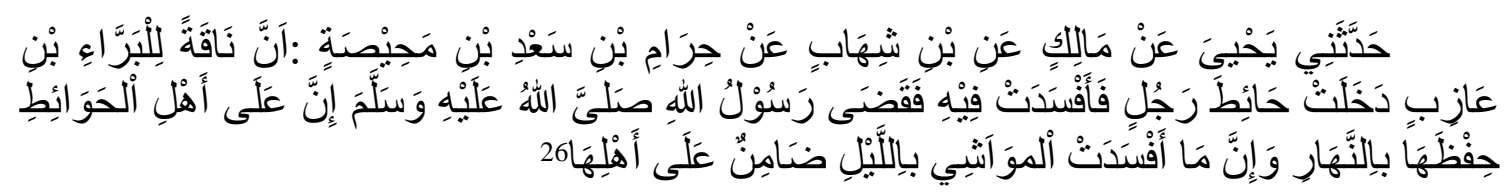

'Bahwa unta milik Barra' bin 'Azib telah memasuki pagar kebun milik seseorang

${ }^{24}$ Al-Shatibi, al-Muwafaqat, Jilid II, 230.

${ }^{25}$ A. Qadri Azizy. Eklektisme Hukum Nasional, 174

${ }^{26}$ Malik bin Ans al-Asbahy, Muwatta' al-Imam al-Malik, Jilid. II (Mesir: Dar Ihya' al-Turath al-

'Araby, t.th), 747 
dan merusaknya. Lalu Rasulullah memberikan putusan bahwa sesungguhnya pemilik kebun berkewajiban menjaga kebunnya di siang hari, dan kebun yang dirusak oleh hewan ternak di malam hari, menjadi tanggung jawab pemilik hewan ternak tersebut".

Pada kasus yang tertera tersebut, adanya pemutusan hukum mengenai orang yang bertanggung jawab dalam masalah pengerusakan kebun didasarkan pada sebuah tradisi masyarakat Arab saat itu bahwa perawatan kebun dilakukan oleh pemiliknya di siang hari, sementara hewan ternak dimasukkan ke kandang pada malam hari. Kebiasaan ini berjalan selama bertahun-tahun dan turun-temurun serta dianggap sebagai norma sosial yang dijalani.

Pada taraf inilah, hadis di atas dapat difahami mengenai titik tekan hadis ini, bahwa jika pengerusakan kebun terjadi pada malam hari, maka Barra' harus bertanggung jawab karena dianggap lalai dalam memelihara ternaknya. Akan tetapi bila terjadi pada siang hari, maka Barra' tidak dikenai kewajiban mengganti rugi karena pada siang hari, pemeliharaan harta dibebankan pada pemilik kebun. ${ }^{27}$

Pada sisi kenyataan seperti inilah, pemaknaan sebuah hadis yang berimplikasi pada sebuah hukum, perlu ditelusuri dalam konteks adat istiadat di mana hadis tersebut hadir. Oleh karena itulah, dalam penelaahan sebuah hadis, Yusuf al-Qardawy memberikan sebuah pernyataan yang menarik bahwa "perlu juga mempertimbangkan sebagian dari nash-nash (yang terkandung dalam sunnah nabi) yang berlandaskan pada suatu kebiasaan (tradisi) temporer, yang berlaku pada zaman beliau kemudian mengalami perubahan di masa kini. Tidak ada salahnya jika kita memandang kepada maksud yang dikandungnya, tanpa harus berpegang pada pengertian lahiriyahnya. ${ }^{28}$

Pernyataan itu berimplikasi pada proses pemaknaan yang perlu diusahakan kembali adalah mempertimbangkan unsur lokalitas dalam pembentukan hukum Islam saat itu. Hal ini dikarenakan hukum Islam hadir dengan ruang tradisi dan unsur lokalitas yang melekat. Meskipun hukum Islam diposisikan sebagai hukum yang berlaku secara universal, namun keberadaan unsur lokalitas perlu ditelisik kembali. Ini merupakan upaya menemukan esensi hukum Islam agar tidak terjebak pada hukum Islam yang berlandaskan tradisi yang sementara.

2. Harta Bersama dalam Pembagian Waris

Pada tataran teoritis, harta dalam pembagian waris dibagi apa adanya sesuai dengan ketentuan hukum Islam yang tertera dalam al-Quran maupun hadis. Ketentuanketentuan dalam hukum waris pada harta tersebut dilakukan setelah salah satu dari suami atau istri meninggal dunia. Pembagian waris yang kontroversial mengemuka setelah terjadi pembagian hukum waris dilaksanakan setelah harta bersama dibagi merata antara suami/istri yang masih hidup, kemudian separuhnya dijadikan sebagai harta warisan. Pada dasarnya Islam tidak mengenal istilah "harta bersama".

Namun dalam realitas kultural di Indonesia, misalnya, mengenal sebuah pembagian harta dalam perkawinan yang dibedakan menjadi harta bawaan dan harta bersama. Harta bersama, atau lazim disebut gono-gini, menjadi harta yang perolehannya dianggap secara bersama oleh suami dan istri. Harta bersama ini memberikan implikasi yang berbeda dalam praktek pembagian harta waris, di mana harta bersama dibagi dua terlebih dahulu lalu separuh diberikan kepada suami/istri yang masih hidup, dan sisanya dibagi berdasarkan ketentuan dalam hukum waris.

27 Taqiyuddin Abu Bakr Muhammad bin Abdul Mun'im al-Hisny, Kitab al-Qawaid (Riyad\}: Maktabat al-Rushd, 1997), 358-359.

28 Yusuf Qardhawi, Bagaimana Memahami Hadis Nabi SAW, pent: Muhammad al-Baqir, Cet.V (Bandung: Karisma, 1997), 57. 
Abdurrahman Wahid beranggapan hal inilah yang mendasari bahwa pembagian harta waris turut mengalami akulturasi dengan budaya lokal dalam penyesuaianpenyesuaian bentuk. ${ }^{29}$ Atas unsur lokalitas ini pula, peraturan mengenai harta benda dalam perkawinan yang tertera dalam Pasal 35 Ayat 1 UU. No.1 Tahun 1974 Tentang Perkawinan memberikan definisi yang jelas bahwa "Harta benda diperoleh selama perkawinan menjadi harta bersama".

Ini berarti, harta yang didapatkan selama perkawinan menjadi harta bersama-sama antara seorang suami dan istri. Jikalau salah satu meninggal dunia, maka harta tersebut dibagi menjadi dua, kemudian sisa separuh milik si mayit dijadikan harta yang diwarisi keluarga. Sistem hukum pembagian harta waris inilah yang telah mengalami pergesekan dengan unsur lokalitas yang bukan hanya tidak saling menegasikan, namun malah justru memunculkan wajah baru Hukum Islam yang lebih akomodatif, ramah, dan bernuansa keadilan.

\section{Hukum Islam dan Budaya Lokal, Diskursus yang Selalu Terbuka}

Pemaparan ini tidaklah berlebihan jikalau memunculkan sebuah kesimpulan bahwa persinggungan unsur budaya budaya lokal justru mampu menampilkan sebuah ragam, atau paling tidak, mewarnai dalam pembentukan Hukum Islam. Maka, diskursus Islam dan Budaya, pada tataran yang lebih luas bukan hendak mempertentangkan sesuatu yang memang berlainan, namun mencoba menggali nilai harmoni antara keduanya dengan menelaah lebih dalam mengenai Islam, beserta seperangkat aturannya, dengan unsur lokalitas di mana Islam tumbuh dan berkembang.

Dengan melihat unsur lokalitas di mana Islam tumbuh dan berkembang, diharapkan akan semakin memberikan sebuah pemahaman yang lebih komprehensif mengenai pembentukan hukum Islam, seperti yang pernah ditunjukkan oleh Taha Husayn dalam merujuk realitas adat pra-Islam. Bahwa menurut Taha Husayn, dalam faktanya, Islam banyak mewarisi peninggalan-peninggalan bangsa Arab serta mengadopsi sistem (pranata) yang berkembang di kalangan mereka. ${ }^{30}$

Dalam hal ibadah, Islam menjalankan ibadah haji dan umrah sebagaimana telah dipraktekkan dalam masyarakat Arab jauh sebelum Islam datang. Masyarakat Arab menjalankan ritual-ritual tersebut sebagaimana dijalankan oleh umat Islam sekarang ini, yaitu: talbiyyah, ihram, wuquf dan lain sebagainya. Setelah kedatangan Islam, kemudian praktek tersebut diteruskan dengan penggunaan istilah yang sama. Akan tetapi Islam kemudian membersihkan ibadah ini dari perilaku syirik, seperti ungkapan-ungkapan talbiyyah mereka yang masih bernuansa syirik. Di samping itu Islam juga melarang bertawaf secara telanjang. ${ }^{31}$

Selain dalam hal ibadah, hukum Islam juga mengadopsi budaya yang lain, misalnya sistem qisas dan diyat. Kedua hal tersebut merupakan praktek budaya masyarakat praIslam kemudian diadopsi dalam hukum pidana Islam ${ }^{32}$. Jika merunut pada realitas pra Islam tersebut, lalu dihubungkan dengan Islam dan pembentukan hukumnya, adopsi aspek lokalitas tersebut dapat dilegitimasi dengan beberapa hal:

\footnotetext{
${ }^{29}$ Abdurrahman, "Pribumisasi Islam", 84

30 Khalil Abdul Karim, Syari'ah Sejarah Perkelahian Pemaknaan, terj. Kamran As'ad, Yogyakarta, LkiS, 2003, x

${ }^{31}$ Ibid., 7

${ }^{32}$ Ratno Lukito, Pergumulan antara Hukum Islam dan Hukum Adat di Indonesia, (Jakarta: INIS, 1998).
} 
1. Adanya dalil/landasan tekstual yang ditengarahi memberikan legitimasi akan hal ini.

2. Para ulama telah bersepakat bahwa, tradisi atau kebiasaan bisa dijadikan sebagai hukum dalam hal-hal yang telah berulang-berulang dilakukan menurut adat kebiasaan, karena hal itu terlahir dari hajat dan kemaslahatan yang tidak bertentangan dengan nuṣus al-shar'i (nas syara') dan tujuan-tujuan umumnya.

Kadang-kadang masyarakat pada zaman nabi SAW terbiasa melakukan suatu perkara yang berkaitan dengan perihal kehidupan mereka dan Nabi tidak mengharamkan hal itu, ini membuktikan hal tersebut boleh dilakukan. Maka adat atau tradisi merupakan landasan hukum dalam perkara-perkara yang baru pada setiap zaman dan tempat. ${ }^{33}$

3. Syari'at telah diturunkan dengan tujuan mewujudkan kemaslahatankemaslahatan bagi hamba-hambanya, dan termasuk yang mencerminkan kemaslahatan adalah, hendaknya diperhatikan tradisi dan kebiasaan mereka yang disenangi, yakni tradisi atau kebiasaan yang mereka lakukan dan menganggapnya baik dan mereka sukai.

Oleh karenanya, sewajarnya 'urf itu dianggap dan diakui sebagai salah satu sumber dari sumber-sumber hukum Islam, dengan catatan harus ada ketentuan-ketentuan dan syarat-syarat tertentu, yang menjadikannya justru tidak bertentangan dengan ajaran Islam. ${ }^{34}$ Yusuf Qardhawi pernah memberikan sebuah konklusi menarik dalam menjelaskan 'urf (unsur lokalitas) dapat dijadikan bahwa unsur lokalitas merupakan bagian tidak terpisahkan dari manusia, maka dalam merumuskan hukum, para ulama usuliyun selalau memosisikan 'urf sebagai salah satu instrumen penting. ${ }^{35}$

\section{E. Penutup}

Pada bagian ini, pembahasa mengenai pertautan hukum Islam dan budaya lokal dapat terungkap beberapa kesimpulan, di antaranya, pertama, dalam tataran definitif, Hukum Islam diartikan sebagai seperangkat peraturan berdasarkan wahyu Allah dan Sunnah Rasul tentang tingkah laku manusia muallaf yang diakui dan diyakini berlaku dan mengikat untuk semua umat yang beragama Islam. Sementara budaya, dan atau kebudayaan merupakan pikiran, akal budi, hasil dari penciptaan atau akal budi manusia. Atau dapat juga diartikan sebagai keseluruhan cara hidup manusia.

Kedua, bahwa akulturasi pembentukan Hukum Islam dengan unsur lokal bukan hanya mendapatkan legitimasi dari tekstual al-Quran dan Hadis, namun juga opini rasional yang memperkuatnya, serta Ketiga, perumusan hukum Islam dengan mempertimbangkan tradisi sebagai instrumen yang penting hendaknya dapat diperhatikan dan dikaji dengan cakupan yang lebih luas dan mendalam. Hal ini bukan saja karena landasan argumentasi tradisi dalam hukum Islam yang debatable, namun juga dalam tataran praktis hal ini akan terus dan sering kali akan berbenturan dengan ajakan purifikasi (pembersihan/pemurnian) ajaran kaum puritan. Maka, diskursus Hukum Islam dan nuansa lokalitas akan selalu terbuka dan multitafsir.

\footnotetext{
${ }^{33}$ Abdul Aziz Muhammad Azzam, al-Qawā'id al-Fiqhiyyah, (Kairo: Dar al-Hadith, 2005), 173174.

${ }^{34}$ Amir Abdul Aziz, Ușūl al-Fiqhi al-Islāmiy, al-Mujallad II (Mesir: Dar al-Salam, 1997), 507.

35 Yusuf Qardhawi, Keluwesan dan Keluasan Syari'ah Islam Dalam Menghadapi Perubahan Zaman, terj. Tim Pustaka Firdaus (Jakarta: Pustaka Firdaus, 1996), 30.
} 


\section{DAFTAR PUSTAKA}

A. Qadri Azizy. Eklektisisme Hukum Nasional: Kompetensi antara Hukum Islam dan Hukum Umum, .Yogyakarta: Gama Media. 2002.

Abdul Aziz Muhammad Azzam. al-Qawā'id al-Fiqhiyyah. Kairo: Dar al-Hadith, 2005.

Abdul Karim Zaydan, al-Wajiz fi Usul al-Fiqh. t.t: Muassasat al-Risalah. 2001.

Abu Abdillah Ahmad bin Hanbal al-Shaybani. Musnad Ahmad bin Hanbal, Juz.I. alQahirah: Muassasat Qurtuba, t.th.

Amir Abdul Aziz. Ușūl al-Fiqhi al-Islāmiy, al-Mujallad II. Mesir: Dar al-Salam, 1997.

Burnu (al), Muhammad Sidqy bin Ahmad. al-Wajiz fi Idah Qawa'id al-Fiqh al-Kulliyat. al-Riyad: Muassasat al-Risalah, t.th.

Dede Rosyada. Hukum Islam dan Pranata Sosial; Dirasah Islamiyah III. Jakarta: Rajawali Press 1993.

Hasby Ash-Shiddiqie. Filsafat Hukum Islam. Jakarta: Bulan Bintang. 1975.

Ismail Muhammad Syah (et.al). Filsafat Hukum Islam, cet.III. Jakarta: PT Bumi Aksara. 1999.

Khalaf, Abd. Wahhab. Ilm Usul Fiqh. Indonesia: al-Haramayn. 2004.

Khalil Abdul Karim. Syari'ah Sejarah Perkelahian Pemaknaan, terj. Kamran As'ad, Yogyakarta. LkiS. 2003.

Malik bin Ans al-Asbahy. Muwatta' al-Imam al-Malik. Jilid. II. Mesir: Dar Ihya' alTurath al-'Araby. t.th.

Mohd. Idris Ramulyo. Asas-Asas Hukum Islam; Sejarah Timbul dan Berkembangnya Kedudukan Hukum Islam dalam Sistem Hukum di Indonesia. Jakarta: Sinar Grafika. 1995.

Muntaha Azhari dan Abdul Mun'im Saleh (Ed.). Islam Indonesia Menatap Masa Depan. Jakarta: P3M. 1989.

Parsudi Suparlan (ed). Manusia, Kebudayaan dan Lingkungannya. Jakarta: Rajawali, 1984.

Peter L. Berger dan Thomas Luckmann. The Social Construction Of Reality: A Treatise in The Sociology Of Knowlodge. London: Penguin Group. 1991. 
Ratno Lukito. Pergumulan antara Hukum Islam dan Hukum Adat di Indonesia,. Jakarta:INIS, 1998.

Shatibi (al), Abu Ishaq Ibrahim bin Musa al-Lakhmi al-Ghirnati al-Maliki alMuwafaqat fi Usul al-Shari'ah, j.III. Beirut: Dar al-Ma'rifah.1975.

Sunnah, Ahmad Fahmi Abu. al-'Urf wa al-Adah fi Ra'y al-Fuqaha. Mesir: Dar al-Fikr, al-'Arabi, t.th.

Suyuti (al), Jalal al-Din Abd. al-rahman bin Abi Bakr. al-Ashbah wa al-Nazair fi alFuru. Surabaya: al-Hidayah. 1965.

Syahrowardi dan M. Imdad Robbani (eds). Formulasi Nalar Fiqh; Telaah Kaedah Fiqh Konseptual. Surabaya: Khalista, 2006.

Taqiyuddi $>$ n Abu Bakr Muhammad bin Abdul Mun'im al-H\} \}is \}ny. Kitab al-Qawa >id Riya>d \}: Maktabat al-Rushd. $1997 .^{1}$

Tim Penyusun Kamus Pusat Bahasa. Kamus Bahasa Indonesia. Jakarta: Pusat Bahasa. 2008.

Yusuf Qardhawi. Bagaimana Memahami Hadis Nabi SAW, pent: Muhammad al-Baqir, Cet.V. Bandung: Karisma. 1997.

Keluwesan dan Keluasan Syari'ah Islam Dalam Menghadapi Perubahan Zaman, terj. Tim Pustaka Firdaus. Jakarta: Pustaka Firdaus. 1996.

Zuhayly (al), Wahbah bin al-Mustafa, al-Tafsir al-Munir fi al-'Aqidah wa al-Shariah wa al-Minhaj, Juz.ix (Damaskus: Dar al-Fikr, 1418 H. 